\title{
6. MINERALOGY AND PETROGRAPHY OF LEG 46 BASALTS
}

\author{
C. Mevel, Laboratoire de Pétrographie, Université Paris VI, Paris, France \\ and \\ D. Ohnenstetter and M. Ohnenstetter, Laboratoire de Pétrographie, Université de Nancy I, c/o 14054037 Nancy Cedex
}

\section{INTRODUCTION}

Leg 46 basalts were recovered at Hole 396B, approximately $160 \mathrm{~km}$ east of the Mid-Atlantic Ridge. Basalts 13 million years old, overlain by 150 meters of sediment, have been divided on board ship into eight lithological units, subsequent to petrographic, magnetic, and chemical studies. The upper lithological unit $(165 \mathrm{~m})$ is composed of pillows, except for Unit 3, which is a large cooling unit. The lower part is built up of pillow breccias and hyaloclastites. The freshest basalts, slightly vesicular, more often with plagioclase and olivine phenocrysts, were sampled from Units 1 to 4 for chemical and mineralogical studies: 32 basalts were examined in thin section and their bulk chemistry was determined. Electron microprobe analyses were performed on pyroxene, plagioclase, olivine, and titanomagnetite from 12 representative samples.

\section{PETROGRAPHY}

Texture, secondary products, and the size variation of the magmatic minerals are shown in Table 1. Thin sections of the basaltic rocks show varying degrees of alteration. The groundmass is always transformed, in varying degree, into smectites. Vesicles are filled with smectites and locally with calcite. Some cross-cutting veins show a similar mineralogy, although zeolites may occur. The two more abundant magmatic minerals, plagioclase and clinopyroxene, are always well preserved. Calcite occurs in cracks in some plagioclase phenocrysts. Olivine is locally transformed into smectites and/or calcite.

Units 1 and 2, separated by interbedded carbonate sediments, consist of fine-grained basalts with sparse olivine and plagioclase microphenocrysts which represent less than 1 per cent of the rocks. Glomerocrysts of these minerals sometimes occur. Plagioclase, olivine, and clinopyroxene are scattered in an abundant groundmass (nearly $30 \%$ ). In the pillow, rim textures vary from glassy through spherulitic to variolitic, as in Sample 7-2, 42-45 cm. Varioles, small $(0.2$ $\mathrm{mm}$ diameter) in the outer zone, increase in size until (at 0.4 $\mathrm{mm}$ diameter) they become coalescent. In the pillow core, hyalopilitic and hyalo-ophitic textures are the more developed.

Unit 3 is a cooling unit. Macroscopically it is composed of dark gray, medium-grained phyric basalts with sparse olivine and plagioclase phenocrysts; texture is intersertal. The two borders are fine grained.

Lithologic Unit 4, more altered than the units above, is built up of a porphyritic pillow sequence. These basalts are gray and fine grained with 15 to 20 per cent phenocrysts.
Plagioclase phenocrysts are five times more abundant than olivine phenocrysts. Plagioclase and olivine glomeroporphyritic clots are locally present. Brown chrome spinel occurs as inclusions in plagioclase and as isolated phenocrysts in the groundmass. Plagioclase microlites with pronounced skeletal shape are locally oriented in the abundant mesostatis.

We have examined one sample from lowermost Unit 5. It is grayish brown fine-grained basalt with many patches and veins of calcite and zeolites. The texture is hyalopilitic and trachytic.

\section{CHEMISTRY}

\section{Analytical Method}

Major elements of 32 basalts have been determined by P. Cambon at the COB using an X-ray fluorescence method similar to that used for shipboard analyses (Bougault and Cambon, 1973; Bougault, in press). Glass and varioles (39 analyses) from Sample 7-2, 73-75 cm, were analyzed using the microprobe. The analytical method is similar to that employed for mineralogical determination (see below). The results are given in Table 2, where chemical and lithologic units are also specified. The bulk chemistry is characteristic of abyssal tholeiites. $\mathrm{MgO}$ and $\mathrm{SiO}_{2}$ are nearly constant, and $\mathrm{K}_{2} \mathrm{O}$ is always low in every unit.

Units 2 and $3\left(\mathrm{~A}_{3}\right)$ contain more $\mathrm{Ti}, \mathrm{Fe}, \mathrm{P}$, and $\mathrm{Mn}$ than Unit $1\left(A_{1}-A_{2}\right)$. In Unit 1 , the upper part $\left(A_{1}\right)$ is poorer in $T i$ than the lower $A_{2}$. The basalts of Unit 4 (B) are high-alumina tholeiites if the 16.4 per cent $\mathrm{Al}_{2} \mathrm{O}_{3}$ limit is used (Miyashiro et al., 1969). The $\mathrm{Al}_{2} \mathrm{O}_{3}$ and $\mathrm{CaO}$ enrichment, coupled with low $\mathrm{FeO}, \mathrm{TiO}_{2}, \mathrm{P}_{2} \mathrm{O}_{5}$, and $\mathrm{MnO}$ contents when compared with Unit A, may be correlated at first with the abundance of the plagioclase phenocrysts. The fundamental differences in $\mathrm{Al}_{2} \mathrm{O}_{3}$ and $\mathrm{TiO}_{2}$ contents between Units $\mathrm{A}$ and $\mathrm{B}$ and their sub-units may be easily checked in the $\mathrm{Al}_{2} \mathrm{O}_{3}-\mathrm{TiO}_{2}$ diagram (Figure 1).

The correlation between vertical position and differentiation is inverse in Units A and B. Unit A shows an apparent $\mathrm{TiO}_{2}$ increase coupled with a slight $\mathrm{Al}_{2} \mathrm{O}_{3}$ decrease towards the base of the unit: a differentiation inverse to the eruption sequence. In contrast, a normal differentiation pattern occurs in Unit $\mathrm{B}$, in which $\mathrm{TiO}_{2}$ increases and $\mathrm{Al}_{2} \mathrm{O}_{3}$ decreases towards the top of the volcanic pile. In each $\mathrm{A}$ sub-unit the differentiation trend is similar: $\mathrm{TiO}_{2}$ increases toward the top of each A sub-unit, especially in $A_{2}$, thus indicating a normal differentiation trend with depth. The apparent reversal evolution of Unit A may be a consequence of fractional crystallization of slightly different magma batches. In Unit $\mathrm{B}$, by contrast, as $\mathrm{Al}_{2} \mathrm{O}_{3}$ decreases and $\mathrm{TiO}_{2}$ 
TABLE 1

Summary of Petrographic Features of Basalts From Hole 396B

\begin{tabular}{|c|c|c|c|c|c|c|c|c|c|c|c|c|}
\hline $\begin{array}{l}\text { Lithologic Unit } \\
\text { Samples } \\
\text { (Interval in } \mathrm{cm})\end{array}$ & Texture & Phenocrysts & $\begin{array}{l}\text { Plagioclases } \\
\text { Microphenocrysts }\end{array}$ & Mictolites & Phenocrysts & $\begin{array}{c}\text { Olivine } \\
\text { Microphenocrysts }\end{array}$ & Microlites & Clinopytoxenes & Opaques & $\begin{array}{l}\text { Glassy Groundmass } \\
\text { More or Less Altered }\end{array}$ & $\begin{array}{l}\text { Alteration } \\
\text { Products }\end{array}$ & $\begin{array}{c}\text { Vesicle } \\
\text { Diameter }\end{array}$ \\
\hline \multicolumn{13}{|l|}{ Unit I } \\
\hline $5-2,134-136, \# 15$ & Intersertal to hyalo-ophitic & & $\begin{array}{l}\text { Glomeroctysts } \\
0.880 .4 \mathrm{~mm}\end{array}$ & $\underset{A}{0.2 / 0.03 \mathrm{~mm}}$ & & $\begin{array}{l}\text { Some euhedral crystals, } \\
\text { sometimes rounded, } \\
0.6 \mathrm{~mm} \mathrm{~A}\end{array}$ & $0.04 \mathrm{~mm}$ & $0.05 \mathrm{~mm}_{\mathrm{A}}$ & Granules & + & $\begin{array}{l}\text { Calcite } \\
\text { smectite }\end{array}$ & + \\
\hline $7 \cdot 1,106-108, \# 10$ & Hyalo-ophitic & & & $0.2 / 0.05 \mathrm{~mm}_{\Lambda}$ & & & $\begin{array}{l}0.05 \mathrm{~mm} \\
\text { anhedral A }\end{array}$ & $\begin{array}{l}\text { Cerviconic and } \\
\text { axiolitic A }\end{array}$ & Granules & + & Calcite & \\
\hline $7 \cdot 2,42 \cdot 45, * 5$ & $\begin{array}{l}\text { Glassy-varioliticic to spheru. } \\
\text { liticivarioles size } 0.2 \text { to } \\
0.4 \mathrm{mmm}\end{array}$ & & & $0.2 / 0.3 \mathrm{~mm}$ & & $\underset{\wedge}{0.8 / 0.2 \mathrm{~mm}}$ & + & + & + & 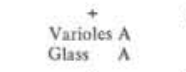 & Calcite & + \\
\hline $7-2,73-75, \# 7 \mathrm{~B}$ & Intersertal & & & $0.6 / 0.02 \mathrm{~mm}$ & & $1.6 / 0.7 \mathrm{~mm}$ rounded & & + & + & + & Smectite & \\
\hline $8 \cdot 2,43 \cdot 4 \mathrm{~S}, \# 4 \mathrm{~B}$ & Hyalo-ophitic & & & $\underset{\wedge}{0.6 / 0.4 \mathrm{~mm}}$ & & & $0.1 \mathrm{~mm} \mathrm{~A}$ & Axiolitic A & Granules & + & Smectite & + \\
\hline $9-1,40-49, \pm 60$ & Hyalo-ophitic & & $0.6 / 0.2 \mathrm{~mm}$ & $0.3 / 0.02 \mathrm{~mm}$ & & & $0.1 \mathrm{~mm} \mathrm{~A}$ & Dendritic A & $\begin{array}{l}\text { Titanomagne- } \\
\text { tite } \mathrm{A}\end{array}$ & + & & $0.1 \mathrm{~mm}$ \\
\hline $9-3,14-16, \# 2 \mathrm{~A}$ & Intersertal & & $0.8 / 0.2 \mathrm{~mm}$ & & & & $0.2 \mathrm{~mm} \mathrm{~A}$ & $\begin{array}{l}\text { Axiolitic A } \\
0.2 / 0.01 \mathrm{~mm}\end{array}$ & $0.2 \mathrm{~mm}$ & + & $\begin{array}{l}\text { Smectite } \\
\text { calcite }\end{array}$ & + \\
\hline $10-1,43-46, \neq 8$ & $\begin{array}{l}\text { Very sparsely phyric, } \\
\text { hyalo-ophitic }\end{array}$ & & $2.1 / 0.2 \mathrm{~mm}$ & & & & $0.03 \mathrm{~mm}$ & Axiolitic & Granules & + & Smeetite & \\
\hline $10-2,59-61, \# 9$ & $\begin{array}{l}\text { Very sparsely phyric, } \\
\text { hyaloophitic }\end{array}$ & $\begin{array}{l}\text { 6/3 mum with melt } \\
\text { inclusions }\end{array}$ & & $0.7 / 0.02 \mathrm{~mm}$ & & & $0.1 \mathrm{~mm}$ & Axiolitic & + & + & $\begin{array}{l}\text { Smectite } \\
\text { caleite }\end{array}$ & \\
\hline $11-1,87 \cdot 99, \# 108$ & Intersertal & & & $0.5 / 0.02 \mathrm{~mm}$ & & & $\begin{array}{l}0.05 \mathrm{~mm} \\
\text { skeletal }\end{array}$ & Axiolitic & Granules & + & $\begin{array}{l}\text { Smectite } \\
\text { calcite }\end{array}$ & \\
\hline $11 \cdot 2,18 \cdot 20, \# 2$ & $\begin{array}{l}\text { Very sparsely phyric, } \\
\text { intersertal }\end{array}$ & & & $0.5 / 0.03 \mathrm{~mm}$ & & $0.5 \mathrm{~mm}$ & $0.5 \mathrm{~mm}$ & Axiolitic A & Granules & * & Smectite & $0.2 \mathrm{~mm}$ \\
\hline $12-4,110-112, \approx 7$ & $\begin{array}{l}\text { Very sparsely phyric, } \\
\text { intersertal }\end{array}$ & & $0.9 / 0.6 \mathrm{~mm}$ & $0.6 / 0.04 \mathrm{~mm}$ & & & $0.2 \mathrm{~mm}$ & Axiolitic & Granules & + & Smectite & \\
\hline 13-2, 137-140, \#13 & Spherulitic & & & $\begin{array}{l}0.2 / 0.02 \mathrm{~mm} \\
\text { bow-ties }\end{array}$ & & & $\begin{array}{l}0.04 \mathrm{~mm} \\
\text { skeletal }\end{array}$ & Dendritic & Granules & + & $\begin{array}{l}\text { Smectite cal- } \\
\text { cite in veins }\end{array}$ & $0.2 \mathrm{~mm}$ \\
\hline $14-1,16-21, \# 3$ & $\begin{array}{l}\text { Very sparsely phyric, } \\
\text { spherulitic }\end{array}$ & & & $\begin{array}{l}0.5 / 0.03 \mathrm{~mm} \\
\text { bow-ties }\end{array}$ & & $1.2 / 1.05 \mathrm{~mm}$ & $0.2 / 0.04 \mathrm{~mm}$ & Axiolitic & Granules & + & Smectite & $\begin{array}{l}0.2 \mathrm{~mm} \text { vesicles and } \\
\text { mafic spherules }\end{array}$ \\
\hline $14-2,113-115,211$ & Intersertal & & $4.3 / 0.1 \mathrm{~mm}_{A}$ & & & & $\begin{array}{l}0.15 \mathrm{~mm} \\
\text { gramular }\end{array}$ & $\begin{array}{l}\text { Axiolitic, fan- } \\
\text { shaped; } 0.1 \mathrm{~mm}\end{array}$ & $\begin{array}{l}\text { Grains } \\
\text { titanomagne- } \\
\text { tite A A }\end{array}$ & + & Smectite & $0.2 \mathrm{~mm}$ \\
\hline $14-3,70-72, * 5 \mathrm{C}$ & $\begin{array}{l}\text { Very sparsely phyric, } \\
\text { intersertal }\end{array}$ & & $0.9 / 1.07 \mathrm{~mm}$ & $0.7 / 0.05 \mathrm{~mm}$ & & & $0.05 \mathrm{~mm}$ & Axiolitic & $\begin{array}{l}\text { Grains } \\
\text { euhedral }\end{array}$ & + & Smectite & \\
\hline \multicolumn{13}{|c|}{ Unit 3} \\
\hline $15-1,120-128, \# 12 t$ & Entersertal & & & $1 / 0.05 \mathrm{~mm}$ & & & $0.05 \mathrm{~mm}$ & $\begin{array}{l}\text { Axiolitic, fan- } \\
\text { shaped }\end{array}$ & Granules & + & Smectite & \\
\hline $15-2,79 \cdot 81, \# 17$ & Intergranular & & $1.6 / 1 \mathrm{~mm}$ & $2 / 0.1 \mathrm{~mm}$ & & & $\begin{array}{l}0.5 \mathrm{~mm} \\
\text { granular A }\end{array}$ & $\begin{array}{l}0.5 \mathrm{~mm} \\
\text { granular A }\end{array}$ & $\begin{array}{l}\text { Grains } \\
0.03 \mathrm{~mm} \text { A }\end{array}$ & $+\mathrm{A}$ & Smectite & $0.2 \mathrm{~nm}$ \\
\hline $15 \cdot 2,99-107,42 \AA$ & $\begin{array}{l}\text { Intersertas to } \\
\text { intereranular }\end{array}$ & & $1.2 / 0.5 \mathrm{~mm}$ & $1.8 / 0.1 \mathrm{~mm}$ & & & $\begin{array}{l}0.1 \mathrm{~mm} \\
\text { grains }\end{array}$ & $\begin{array}{l}0.14 \mathrm{~mm} \\
\text { grains }\end{array}$ & $\begin{array}{l}\text { Grains } \\
\text { skeletal } \\
0.14 \mathrm{~mm}\end{array}$ & + & $\begin{array}{l}\text { Smectite } \\
\text { calcite }\end{array}$ & $0.4 \mathrm{~mm}$ \\
\hline $15-4,114-116,47$ & Intersertal & & $2.5 / 1.5 \mathrm{~mm}$ & $0.8 / 0.05 \mathrm{~mm}$ & & & $\begin{array}{l}0.14 \mathrm{~mm} \\
\text { grains } \\
\text { skeletal A }\end{array}$ & $\begin{array}{l}\substack{0.25 \mathrm{~mm} \\
\text { grains A }} \\
\text {. }\end{array}$ & $\begin{array}{l}\text { Grains } \\
0.07 \mathrm{~mm} \\
\text { skeletal }\end{array}$ & ${ }^{+}$ & Smectite & $0.3 \mathrm{~mm}$ \\
\hline $15-5,16-18, \# 2 B$ & Intersertal & & $3 / 1.4 \mathrm{~mm}$ & $0.2 / 0.08 \mathrm{~mm}$ & & & $\begin{array}{l}\text { Grains } \\
0.07 \mathrm{~mm}\end{array}$ & $\begin{array}{l}\text { Grains } 0.14 \mathrm{~mm} \\
\text { skeletal }\end{array}$ & $\begin{array}{l}\text { Grains } \\
0.07 \mathrm{~mm}\end{array}$ & + & $\begin{array}{l}\text { Smectite } \\
\text { calcite }\end{array}$ & $0.2 \mathrm{~mm}$ \\
\hline \multicolumn{13}{|l|}{ Unit 4} \\
\hline $16-1,28-30, \approx 4$ & $\begin{array}{l}\text { Porphyritic, hyalo-ophitic } \\
\text { to intersertal }\end{array}$ & $\begin{array}{l}3 / 1 \mathrm{~mm} \text { euhedral } \\
\text { melt inclusions }\end{array}$ & & $0.5 / 0.03 \mathrm{~mm}$ & $2 \mathrm{~mm}$ rounded & & $0.14 \mathrm{~mm}$ & Axiolitic A & $\begin{array}{l}\text { Oxides } \\
\text { granules } \\
\text { Cr-spinel }\end{array}$ & + & $\begin{array}{l}\text { Calcite } \\
\text { smectite }\end{array}$ & $0.4 \mathrm{~mm}$ \\
\hline $18-1,55-57, \# 4 \mathrm{C}$ & Porphyritic, intersertal & $\begin{array}{l}\text { 3/1 um melt } \\
\text { inclusions }\end{array}$ & & $0.6 / 0.04 \mathrm{~mm}$ & $1 \mathrm{~mm}$ rounded & & $0.1 \mathrm{~mm} \mathrm{~A}$ & Axiolitic A & $\begin{array}{l}\text { Oxides granules } \\
\text { and Cr-spinel } \\
0.07 \mathrm{~mm}\end{array}$ & + & $\begin{array}{l}\text { Smectite } \\
\text { cakite }\end{array}$ & $\begin{array}{l}0.14 \text { vesicles and } \\
\text { spherules } 1 \mathrm{mmm}\end{array}$ \\
\hline $20-1,65-69, \# 4$ & Porphyritic, hyalo-ophitic & $5 / 3 \mathrm{~mm}$ & & $0.2 / 0.02 \mathrm{~mm}$ & $3 \mathrm{~mm}$ rounded & & $0.16 \mathrm{~mm}$ & Axiolitic & $\begin{array}{l}\text { Grains } \\
0.04 \mathrm{~mm}\end{array}$ & + & $\begin{array}{l}\text { Smectite } \\
\text { calcite }\end{array}$ & $\begin{array}{l}0.6 \mathrm{~mm} \text { vesicles and } \\
\text { mafic spherules; } 0.4 \mathrm{~mm}\end{array}$ \\
\hline
\end{tabular}




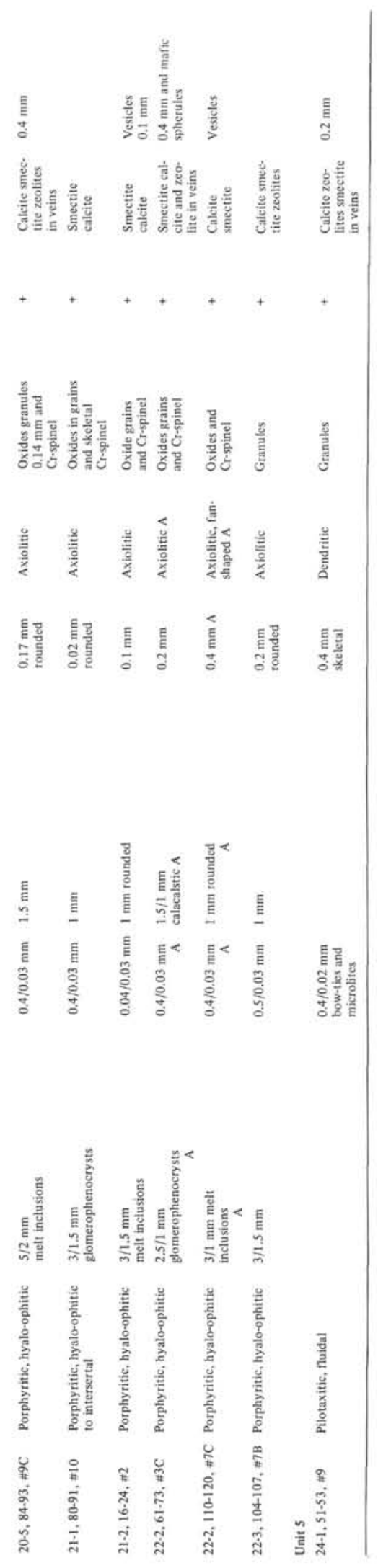

increases from $\mathrm{B}_{2}$ to $\mathrm{B}_{1}$ - towards the top - $\mathrm{B}_{1}$ may have been derived from $\mathrm{B}_{2}$ through a plagioclase fractionation.

Variation diagrams relating $\mathrm{FeO} / \mathrm{MgO}$ to $\mathrm{Fe}$ and $\mathrm{Ti}$ oxides show features similar to those noted above (Figure 2). $\mathrm{FeO} / \mathrm{MgO}$ ( 1 to 1.5 ) increases towards the bottom in Unit A and normally towards the top in Unit B. Glass and varioles from Sample 396B-7-2, 42-45 cm are also shown in Figure 2 (by the areas enclosed by solid lines) and reported in Table 3 ; the details of these areas appear in Figure 3. The FeO/MgO ratios of varioles and glass are lower than that of the host rock but similar to those of the Unit A basalts. $\mathrm{MgO}$ depletion in the slightly altered pillow rim would explain in the low $\mathrm{FeO} / \mathrm{MgO}$ ratio of the host rock (Honnorez and Bohlke, in press). Varioles are richer in $\mathrm{TiO}_{2}$ than glass and host rock. Fe distribution is similar in varioles and glass; Fe oxide increases with ratio increase. This trend shown by varioles and glass in a single pillow is similar to the normal evolution of abyssal tholeiites. The narrow compositional range between varioles and basalts excludes an immiscibility process for the variole genesis. Undercooling is the more probable explanation of their formation (Lofgren, 1974).

\section{PHASE CHEMISTRY}

Electron microprobe analyses were obtained for 12 samples of lithologic Units 1 to 4 . The minerals were analyzed using the CAMECA MS 46 microprobe at the University of Paris. The analytical conditions were as follows: accelerating voltage $15 \mathrm{kV}$, specimen current 30 $\mathrm{nA}$, counting time 50 seconds for olivine and pyroxene and 25 seconds for plagioclase. Natural minerals were used as standards. The microprobe data were reduced on the CIRCE IBM 370 computer employing the EMPEDAR program (Rucklidge and Gasparini, 1969). In Sample 396B-7-2, $42-45 \mathrm{~cm}$, the fine grain size of the pryoxenes does not permit their analyses. This is also true for opaque oxides in many samples.

We analyzed 243 pyroxene samples, using the microprobe. Representative selected samples are reported in Table 4 . The pyroxenes, slightly brown in thin section and scattered in the groundmass, constitute one of the last crystallizing phases. The habit is axiolitic, dendritic, and comb-like (except in the cooling unit of Core 15, where it is more often granular). These pyroxenes fall always in the augite-salite field for Units 1, 2, and 4. The pyroxenes of the cooling unit are restricted to the augite field. $\mathrm{Al}_{2} \mathrm{O}_{3}$ and $\mathrm{TiO}_{2}$ contents are high and show wide varations throughout the unit. $\mathrm{TiO}_{2}$ contents of Units 1 and 2 are the highest. In the porphyritic basalt of Unit $4, \mathrm{Al}_{2} \mathrm{O}_{3}$ content reaches the highest values (up to $8.69 \%$ ).

In the $\mathrm{Ca}-\mathrm{Mg}-\mathrm{Fe}$ diagram (Figure 4, pyroxenes of Unit 1 fall in the same field, despite the dispersion. There is no obvious trend, only a slight $\mathrm{Fe}-\mathrm{Mg}$ variation. Sample 396B-5-2, 134-136 cm exhibits a Mg-Ca variation. In Unit 2, pyroxenes of the analyzed sample fall in the same area, but $\mathrm{Mg}$ is nearly constant. In Unit 3, pyroxenes fall in the augite field and are relatively more magnesium-rich than pyroxenes of the unit above. An iron-enrichment trend at nearly constant $\mathrm{Mg}$ is evident for the two analyzed samples. Such a trend is usually considered a result of rapid metastable crystallization linked to undercooling (Kirkpatrick, 1976). This trend is curiously well-developed in this cooling unit 
TABLE 2

Chemical Analyses of the Basalts From Hole 396B

\begin{tabular}{|c|c|c|c|c|c|c|c|c|c|c|c|c|c|c|c|}
\hline Sample & $\begin{array}{c}5-2 \\
134-136\end{array}$ & $\begin{array}{l}7-1 \\
\# 10\end{array}$ & $\begin{array}{l}7 \cdot 2 \\
\# 5\end{array}$ & $\begin{array}{c}7-2 \\
\# 7 \mathrm{~B}\end{array}$ & $\begin{array}{c}8-2 \\
\# 4 B\end{array}$ & $\begin{array}{l}9-1 \\
\# 6 \mathrm{D}\end{array}$ & $\begin{array}{c}9.3 \\
\# 2 \mathrm{~A}\end{array}$ & $\begin{array}{l}10-1 \\
\# 8\end{array}$ & $\begin{array}{l}10-2 \\
\# 9\end{array}$ & $\begin{array}{c}11-1 \\
\# 10 \mathrm{~B}\end{array}$ & $\begin{array}{c}11-2 \\
\# 2\end{array}$ & $\begin{array}{c}12-1 \\
\# 7\end{array}$ & $\begin{array}{l}13-2 \\
\# 13\end{array}$ & $\begin{array}{c}14-1 \\
\# 3\end{array}$ & $\begin{array}{l}14-2 \\
\# 11\end{array}$ \\
\hline Lithological Unit & 1 & 1 & 1 & 1 & 1 & 1 & 1 & 1 & 1 & 1 & 1 & 1 & 1 & 2 & 2 \\
\hline Chemical Unit & $A_{1}$ & $A_{1}$ & $\mathrm{~A}_{1}$ & $\mathrm{~A}_{1}$ & $\mathbf{A}_{1}$ & $\mathrm{~A}_{2}$ & $\mathrm{~A}_{2}$ & $A_{2}$ & $A_{2}$ & $A_{2}$ & $A_{2}$ & $\mathrm{~A}_{2}$ & $\mathrm{~A}_{2}$ & $\mathrm{~A}_{3}$ & $\mathrm{~A}_{3}$ \\
\hline $\mathrm{SiO}_{2}$ & 49.46 & 49.90 & 48.82 & 49.41 & 49.44 & 48.99 & 50.22 & 49.89 & 49.22 & 49.19 & 49.46 & 50.01 & 49.23 & 48.91 & 49.52 \\
\hline $\mathrm{Al}_{2} \mathrm{O}_{3}$ & 15.22 & 15.72 & 16.02 & 15.24 & 15.15 & 15.95 & 15.50 & 14.91 & 15.23 & 15.06 & 15.03 & 14.93 & 15.22 & 15.21 & 15.09 \\
\hline $\mathrm{Fe}_{2} \mathrm{O}_{3}^{+}$ & 10.37 & 10.01 & 10.93 & 10.14 & 10.45 & 11.24 & 9.92 & 10.31 & 10.53 & 10.74 & 10.55 & 10.58 & 10.72 & 11.28 & 11.11 \\
\hline $\mathrm{MnO}$ & 0.17 & 0.17 & 0.18 & 0.16 & 0.17 & 0.18 & 0.15 & 0.16 & 0.17 & 0.17 & 0.17 & 0.16 & 0.18 & 0.18 & 0.17 \\
\hline $\mathrm{MgO}$ & 8.08 & 7.77 & 6.80 & 8.42 & 8.03 & 6.89 & 7.10 & 7.60 & 7.38 & 7.75 & 7.50 & 7.65 & 7.74 & 7.80 & 7.37 \\
\hline $\mathrm{CaO}$ & 12.00 & 12.24 & 12.29 & 11.80 & 11.57 & 12.26 & 11.93 & 11.51 & 11.88 & 11.59 & 11.55 & 11.48 & 11.65 & 11.23 & 11.11 \\
\hline \multicolumn{16}{|l|}{$\mathrm{Na}_{2} \mathrm{O}$} \\
\hline $\mathrm{K}_{2} \mathrm{O}$ & 0.28 & 0.24 & 0.17 & 0.23 & 0.27 & 0.27 & 0.23 & 0.28 & 0.26 & 0.24 & 0.24 & 0.26 & 0.15 & 0.26 & 0.26 \\
\hline $\mathrm{TiO}_{2}$ & 1.42 & 1.43 & 1.48 & 1.41 & 1.52 & 1.61 & 1.59 & 1.56 & 1.53 & 1.54 & 1.54 & 1.52 & 1.55 & 1.67 & 1.65 \\
\hline $\mathrm{P}_{2} \mathrm{O}_{5}$ & 0.15 & 0.13 & 0.16 & 0.13 & 0.14 & 0.18 & 0.15 & 0.15 & 0.15 & 0.14 & 0.15 & 0.13 & 0.15 & 0.18 & 0.17 \\
\hline L.O.I. $110^{\circ}$ & 0.70 & 0.29 & 0.87 & 0.65 & 1.42 & 0.93 & 0.50 & 1.36 & 0.59 & 0.64 & 0.41 & 1.21 & 0.40 & 0.66 & 0.35 \\
\hline L.O.I. $1050^{\circ}$ & 0.38 & 0.59 & 0.66 & 0.46 & 1.24 & 0.70 & 0.64 & 0.88 & 0.67 & 0.38 & 0.45 & 1.01 & 0.38 & 0.65 & 0.68 \\
\hline
\end{tabular}

composed of the largest minerals. Nevertheless, the presence of altered glass testifies to the efficiency of rapid cooling. This trend is also recognizable in Unit 4 pyroxenes, which are slightly richer in $\mathrm{Ca}$ and $\mathrm{Mg}$.

\section{Plagioclases}

Selected plagioclase analyses, reported in Table 5, have no $\mathrm{K}$-feldspar component. Plagioclase microlites show a narrow compositional range of An63-73. The highest An values occur in Unit 2. In Unit 3 two generations of feldspar may be present. The big ones are calcic (An65-71) than the small ones (An47-51). The plagioclase phenocryst of Unit 4 has a nearly constant composition in the core (An75-85; 75-89); the narrow rim is more sodic (An64-68; 70-75) and shows values similar to those of the coexisting microlites (An65-73).

\section{Olivines}

Selected olivines are reported in Table 6. Olivine is magnesian in all the units (Fo78-88). Unit 4 exhibits the more magnesian olivine (Fo83-88). Olivine phenocrysts do not appear to be significantly zoned, and have the same composition as the olivine microlites.

\section{Opaque Oxides}

Titanomagnetites were analyzed in Samples 396B-9-1, $40-49 \mathrm{~cm}$ and 396B-14-2, 113-115 cm. Partial analyses are summarized in Table 7. The FeO- $\mathrm{TiO}_{2}$ contents are similar to those reported by Mazzullo et al. (1976).

\section{CONCLUSION}

1. Bulk chemistry and chemical data are consistent with the lithologic and chemical unit defined aboard ship. Basalts are typically abyssal tholeiites; the Unit 4 porphyritic basalts are high-alumina tholeiites.
2. Unit A is more fractionated than Unit B. Unit A shows an apparent inverse evolution with depth, whereas in Unit B the upper basalt may have evolved from the lower basalt through a plagioclase fractionation.

3. Varioles have a compositional range similar to that of the basalt, and were formed by an undercooling process.

4. Augite and salite from Units 3 and 4 show a $\mathrm{Fe}-\mathrm{Ca}$ variation at nearly constant $\mathrm{Mg}$, a feature characteristic of metastable crystallization which occurs during undercooling.

\section{REFERENCES}

Bougault, H., in press. Major elements: analytical chemistry on board and preliminary results.

Bougault, H. and Cambon, P., 1973. Dispersive X-ray fluorescence analysis on board oceanographic vessels. Marine Geology, v. 15 , p. $37-41$.

Honnorez, J. and Bohlke, J.K., in press. Oxidation front during the low-temperature submarine alteration of Mid-Atlantic Ridge basalts, EOS.

Kirkpatrick, R.J., 1976. Towards a kinetic model for the crystallization of magma bodies, J. Geophys. Res., v. 81, p. 25-65.

Lofgren, G., 1974. An experimental study of plagioclase crystal morphology: isothermal crystallization, Am. J. Sci., v. 274, p. 243-273.

Mazzullo, L.J., Bence, A.E., and Papike, J.J., 1976. Petrography and phase chemistry of basalts from DSDP Leg 34. In Yeats, R.S., Hart, S.R., et al., Initial Reports of the Deep Sea Drilling Project, v. 34: Washington (U.S. Government Printing Office), p. 245-261.

Miyashiro, A., Shido, F., and Ewing, M., 1969. Diversity and origin of abyssal tholeiite from the Mid-Atlantic Ridge, near $24^{\circ}$ and $3^{\circ} \mathrm{N}$ latitude, Contr. Mineral. Petrol., v. 23, p. 38-52.

Rucklidge, J. and Gasparini, E.L., 1969. Electron microprobe analytical reduction EMPEDAR VII, University of Toronto, Department of Geology. 
TABLE 2 - Continued

\begin{tabular}{|c|c|c|c|c|c|c|c|c|c|c|c|c|c|c|c|c|}
\hline $\begin{array}{l}14-3 \\
\# 5 \mathrm{C}\end{array}$ & $\begin{array}{c}15-1 \\
\# 12 \mathrm{E}\end{array}$ & $\begin{array}{l}15-2 \\
\# 1 \mathrm{~J}\end{array}$ & $\begin{array}{l}15-2 \\
\# 2 \mathrm{~A}\end{array}$ & $\begin{array}{c}15-4 \\
\# 7\end{array}$ & $\begin{array}{l}15-5 \\
\# 2 B\end{array}$ & $\begin{array}{c}16-1 \\
\# 4\end{array}$ & $\begin{array}{l}16-3 \\
\# 4 \mathrm{~B}\end{array}$ & $\begin{array}{l}18-1 \\
\# 4 \mathrm{C}\end{array}$ & $\begin{array}{c}20-1 \\
\# 4\end{array}$ & $\begin{array}{l}20-5 \\
\# 9 \mathrm{C}\end{array}$ & $\begin{array}{l}21-1 \\
\# 10\end{array}$ & $\begin{array}{c}21-2 \\
\# 2\end{array}$ & $\begin{array}{l}22-2 \\
\# 3 C\end{array}$ & $\begin{array}{l}22-1 \\
\# 7 \mathrm{C}\end{array}$ & $\begin{array}{l}22-3 \\
\# 7 \mathrm{~B}\end{array}$ & $\begin{array}{c}24-1 \\
\# 9\end{array}$ \\
\hline 2 & 4 & 4 & 4 & 4 & 4 & 4 & 4 & 4 & 4 & 4 & 4 & 4 & 4 & 4 & 4 & 5 \\
\hline $\mathrm{A}_{3}$ & $\mathrm{~A}_{3}$ & $\mathrm{~A}_{3}$ & $A_{3}$ & $A_{3}$ & $\mathrm{~A}_{3}$ & $\mathrm{~B}_{1}$ & $\mathrm{~B}_{1}$ & $\mathrm{~B}_{1}$ & $\mathrm{~B}_{1}$ & $\mathrm{~B}_{2}$ & $\mathrm{~B}_{2}$ & $\mathrm{~B}_{2}$ & $\mathrm{~B}_{2}$ & $\mathrm{~B}_{2}$ & $\mathrm{~B}_{2}$ & $\mathrm{C}$ \\
\hline 50.19 & 48.86 & 49.25 & 49.71 & 49.78 & 49.59 & 49.47 & 48.97 & 49.29 & 48.82 & 48.62 & 48.78 & 49.14 & 48.36 & 49.17 & 49.42 & 49.10 \\
\hline 15.30 & 15.37 & 14.91 & 15.05 & 15.12 & 15.03 & 17.21 & 17.15 & 17.07 & 16.99 & 17.74 & 17.57 & 17.44 & 18.33 & 17.91 & 17.37 & 16.28 \\
\hline 10.68 & 11.25 & 11.04 & 11.05 & 10.86 & 10.93 & 9.19 & 9.46 & 9.35 & 9.25 & 8.57 & 8.72 & 8.65 & 8.80 & 8.54 & 8.61 & 10.59 \\
\hline 0.16 & 0.19 & 0.17 & 0.16 & 0.17 & 0.18 & 0.15 & 0.15 & 0.15 & 0.15 & 0.14 & 0.14 & 0.13 & 0.15 & 0.14 & 0.14 & 0.17 \\
\hline 7.04 & 7.10 & 7.96 & 7.78 & 7.87 & 7.28 & 6.22 & 7.12 & 6.90 & 7.98 & 7.89 & 7.42 & 7.49 & 7.89 & 7.20 & 7.93 & 7.29 \\
\hline 11.33 & 11.68 & 11.08 & 11.10 & 11.08 & 11.19 & 12.72 & 12.48 & 12.53 & 12.44 & 12.62 & 12.74 & 12.54 & 12.14 & 12.44 & 12.51 & 11.83 \\
\hline 0.27 & 0.28 & 0.09 & 0.17 & 0.18 & 0.32 & 0.17 & 0.20 & 0.21 & 0.22 & 0.14 & 0.20 & 0.17 & 0.28 & 0.10 & 0.12 & 0.26 \\
\hline 1.70 & 1.68 & 1.66 & 1.65 & 1.65 & 1.67 & 1.24 & 1.22 & 1.23 & 1.18 & 1.02 & 1.04 & 1.01 & 0.99 & 0.99 & 1.02 & 1.57 \\
\hline 0.17 & 0.17 & 0.16 & 0.16 & 0.16 & 0.16 & 0.13 & 0.13 & 0.12 & 0.12 & 0.10 & 0.10 & 0.11 & 0.12 & 0.11 & 0.10 & 0.18 \\
\hline 1.63 & 1.00 & 0.33 & 0.90 & 0.87 & 1.20 & 1.21 & 1.54 & 0.99 & 0.77 & 0.90 & 0.70 & 0.78 & 1.25 & 0.72 & 0.63 & 0.66 \\
\hline 1.17 & 1.47 & 0.04 & 0.99 & 0.60 & 0.82 & 1.15 & 1.20 & 0.88 & 0.50 & 1.09 & 1.12 & 1.11 & 2.75 & 1.21 & 0.80 & 0.56 \\
\hline
\end{tabular}

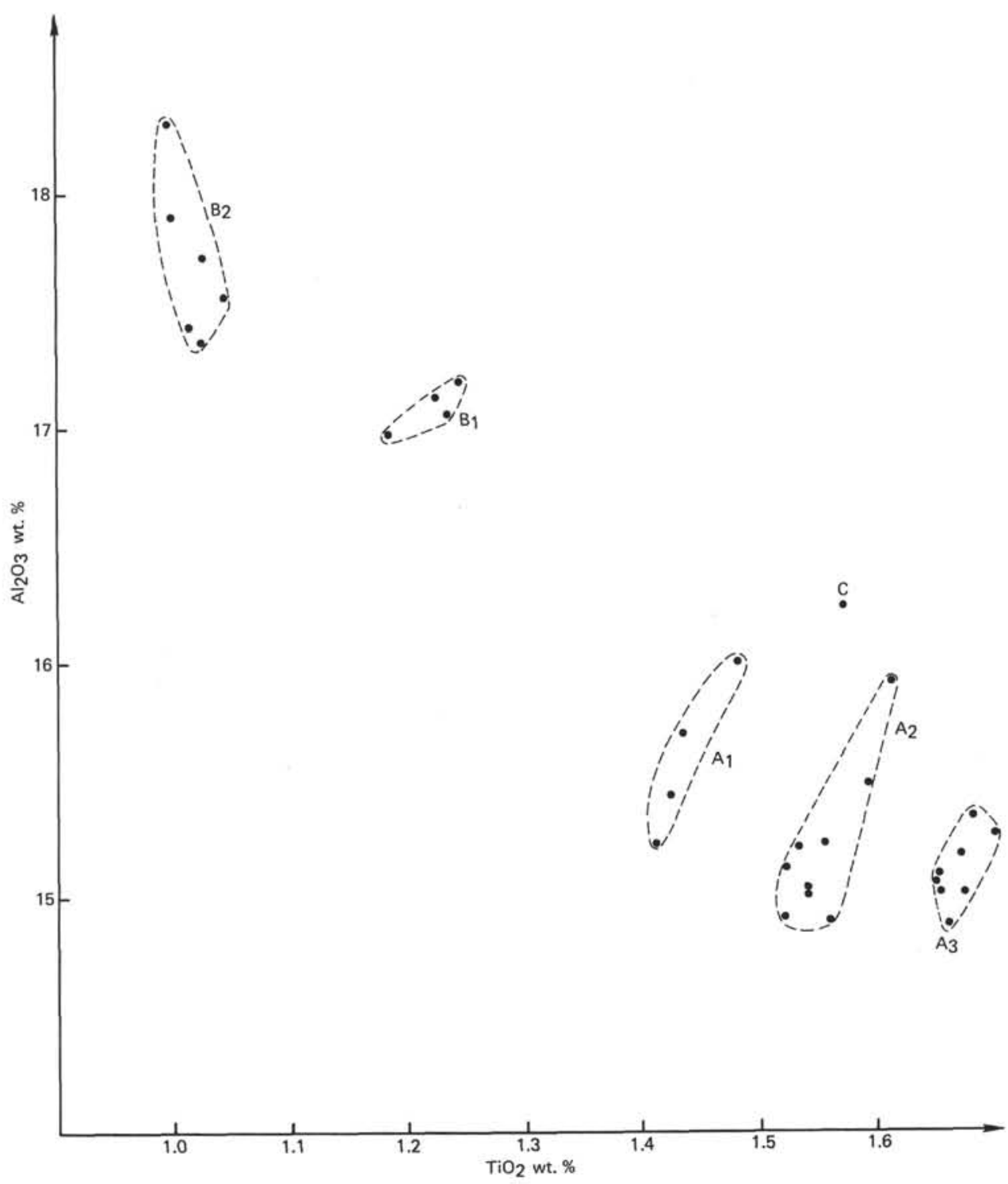

Figure 1. $\mathrm{Al}_{2} \mathrm{O}_{3}-\mathrm{TiO}_{2}$ diagram. 

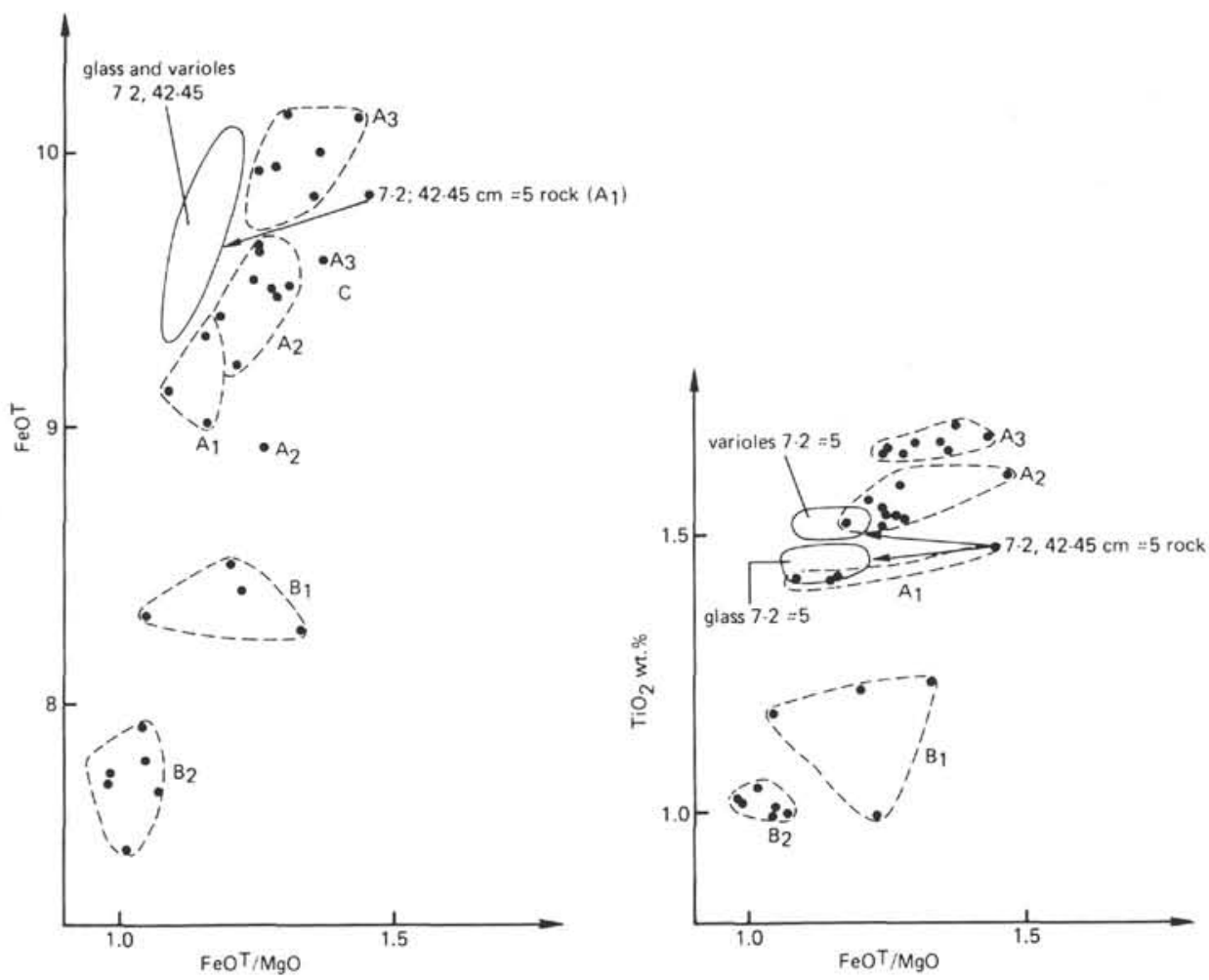

Figure 2. $\mathrm{FeO}^{\mathrm{T}}$ and $\mathrm{TiO}_{2}$ versus $\mathrm{FeO} / \mathrm{MgO}$.

TABLE 3

Chemical Composition of Glass and Varioles of Basalt Sample 396B-7-2, 42-45 cm; Analyzed by Microprobe

\begin{tabular}{l|rrrrrrr}
\hline & \multicolumn{3}{|c}{ Gample } & \multicolumn{2}{|c}{ Glasses } & \multicolumn{3}{c}{ Varioles } & & \multicolumn{3}{c}{ Rim } & Core \\
\hline $\mathrm{SiO}_{2}$ & 49.99 & 49.70 & 50.59 & 49.08 & 49.91 & 49.41 & 48.68 \\
$\mathrm{Al}_{2} \mathrm{O}_{3}$ & 16.72 & 17.18 & 16.01 & 16.82 & 17.58 & 16.20 & 16.10 \\
$\mathrm{Fe}_{2} \mathrm{O}_{3}+$ & 9.55 & 9.48 & 9.65 & 10.22 & 10.98 & 10.12 & 9.72 \\
$\mathrm{MnO}$ & 0.23 & 0.22 & 0.23 & 0.26 & 0.26 & 0.52 & 0.23 \\
$\mathrm{MgO}$ & 8.84 & 8.76 & 8.72 & 9.01 & 6.08 & 8.60 & 8.28 \\
$\mathrm{CaO}$ & 11.24 & 11.34 & 11.83 & 11.11 & 11.58 & 11.44 & 12.05 \\
$\mathrm{Na}_{2} \mathrm{O}$ & 2.35 & 2.18 & 2.16 & 2.25 & 2.29 & 2.59 & 2.59 \\
$\mathrm{~K}_{2} \mathrm{O}$ & 0.15 & 0.13 & 0.10 & 0.09 & 0.17 & 0.14 & 0.08 \\
$\mathrm{TiO}_{2}$ & 1.44 & 1.48 & 1.52 & 1.34 & 1.57 & 1.64 & 1.54 \\
$\mathrm{Total}$ & 100.52 & 100.47 & 100.81 & 100.18 & 100.42 & 100.67 & 99.27 \\
\hline
\end{tabular}



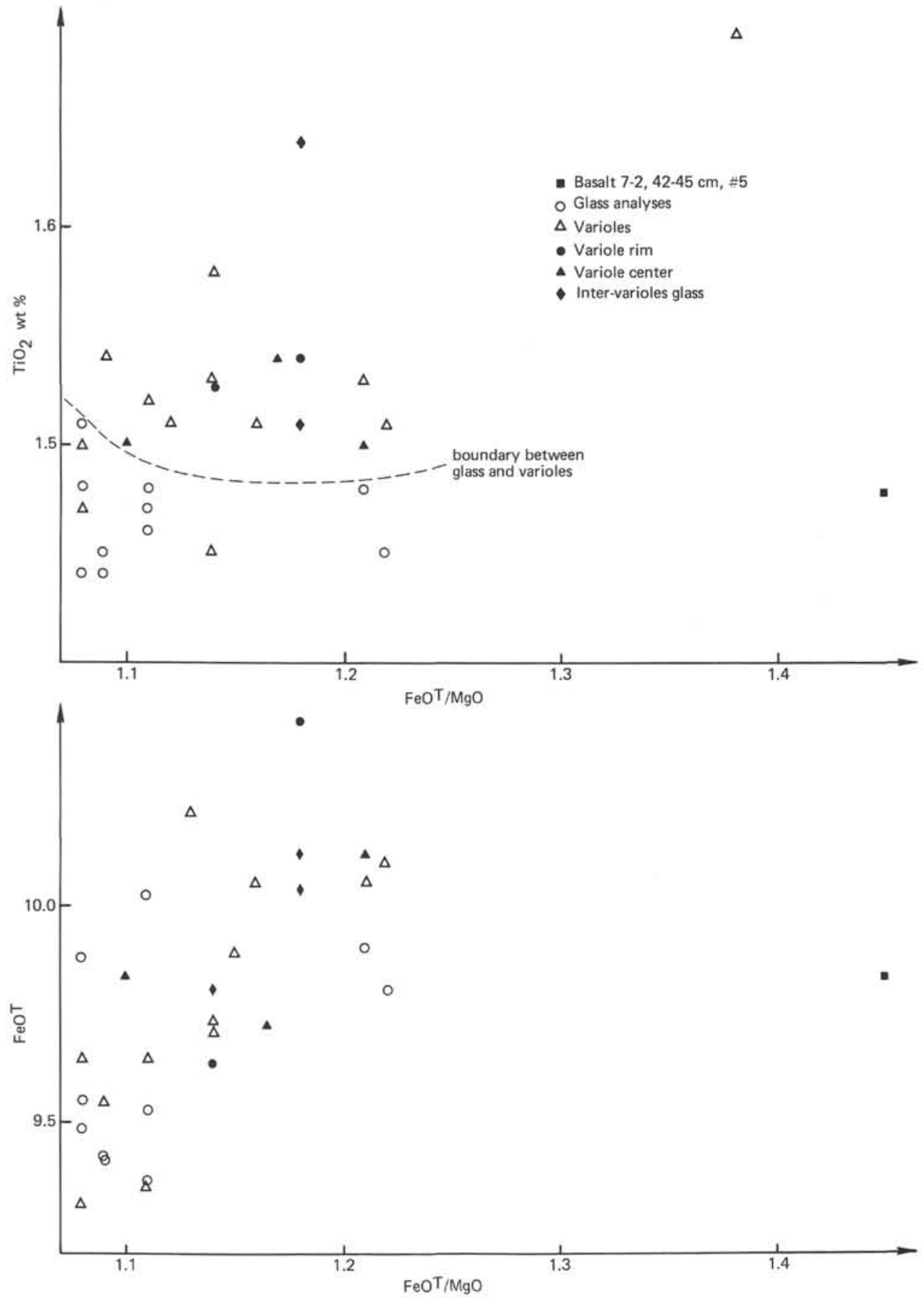

Figure 3. $\mathrm{FeO}^{\mathrm{T}}$ and $\mathrm{TiO}_{2}$ versus $\mathrm{Fe} 0^{T} / \mathrm{MgO}$ for varioles and glass from Sample 7-2, $42-45 \mathrm{~cm}$ basalt. 
C. MEVEL, D. OHNENSTETTER, M. OHNENSTETTER

TABLE 4

Representative Pyroxenes Analyzed by Microprobe

\begin{tabular}{|c|c|c|c|c|c|c|c|c|c|c|c|c|}
\hline \multirow{2}{*}{$\begin{array}{l}\text { Sample } \\
\mathrm{SiO}_{2}\end{array}$} & \multicolumn{3}{|c|}{$5-2,134-136 \mathrm{~cm}$} & \multicolumn{2}{|c|}{$7-1,106-108 \mathrm{~cm}$} & \multicolumn{2}{|c|}{$8-2,43-45 \mathrm{~cm}$} & \multicolumn{2}{|c|}{$11-2,18-20 \mathrm{~cm}$} & \multicolumn{3}{|c|}{$14-2,113-115 \mathrm{~cm}$} \\
\hline & 47.87 & 48.00 & 48.48 & 47.01 & 47.94 & 44.48 & 48.41 & 44.93 & 45.40 & 47.22 & 46.49 & 44.99 \\
\hline $\mathrm{Al}_{2} \mathrm{O}_{3}$ & 5.74 & 5.21 & 6.08 & 5.61 & 5.38 & 5.29 & 3.58 & 4.78 & 5.27 & 5.06 & 4.61 & 6.72 \\
\hline $\mathrm{FeO}^{+}$ & 11.43 & 8.46 & 12.72 & 12.81 & 9.32 & 13.72 & 12.19 & 13.52 & 11.51 & 12.85 & 15.57 & 11.69 \\
\hline $\mathrm{MnO}$ & 0.30 & 0.27 & 0.38 & 0.32 & 0.24 & 0.32 & 0.35 & 0.40 & 0.33 & 0.33 & 0.41 & 0.29 \\
\hline $\mathrm{MgO}$ & 13.29 & 15.47 & 9.76 & 12.18 & 13.61 & 10.17 & 12.11 & 11.67 & 12.01 & 12.70 & 12.64 & 11.76 \\
\hline $\mathrm{CaO}$ & 19.36 & 19.49 & 19.60 & 19.73 & 21.41 & 21.88 & 19.82 & 21.54 & 20.00 & 19.85 & 18.62 & 21.25 \\
\hline $\mathrm{Na}_{2} \mathrm{O}$ & 0.46 & 0.36 & 0.46 & 0.43 & 0.49 & 0.50 & 0.43 & 0.61 & 0.42 & 0.51 & 0.46 & 0.48 \\
\hline $\mathrm{TiO}_{2}$ & 2.12 & 1.70 & 2.53 & 1.96 & 1.66 & 2.55 & 2.14 & 2.26 & 4.07 & 2.30 & 2.36 & 2.89 \\
\hline Total & 100.57 & 98.95 & 100.01 & 100.06 & 100.05 & 99.05 & 99.04 & 99.70 & 99.00 & 100.81 & 101.16 & 100.08 \\
\hline $\mathrm{Si}$ & 1.796 & 1.807 & 1.835 & 1.790 & 1.802 & 1.742 & 1.855 & 1.746 & 1.748 & 1.787 & 1.773 & 1.719 \\
\hline $\mathrm{Al}^{\mathrm{IV}}$ & 0.204 & 0.193 & 0.165 & 0.210 & 0.198 & 0.244 & 0.145 & 0.219 & 0.239 & 0.213 & 0.207 & 0.281 \\
\hline $\mathrm{Al}^{\mathrm{VI}}$ & 0.005 & 0.038 & 0.106 & 0.042 & 0.041 & - & 0.017 & - & - & 0.013 & - & 0.022 \\
\hline $\mathrm{Ti}$ & 0.060 & 0.048 & 0.072 & 0.056 & 0.047 & 0.078 & 0.062 & 0.066 & 0.118 & 0.065 & 0.068 & 0.083 \\
\hline $\mathrm{Fe}$ & 0.359 & 0.266 & 0.403 & 0.408 & 0.293 & 0.450 & 0.391 & 0.439 & 0.370 & 0.407 & 0.497 & 0.374 \\
\hline $\mathrm{Mn}$ & 0.010 & 0.009 & 0.012 & 0.010 & 0.008 & 0.012 & 0.011 & 0.013 & 0.011 & 0.011 & 0.013 & 0.010 \\
\hline $\mathrm{Mg}$ & 0.743 & 0.868 & 0.551 & 0.691 & 0.763 & 0.594 & 0.692 & 0.676 & 0.689 & 0.716 & 0.719 & 0.670 \\
\hline $\mathrm{Ca}$ & 0.778 & 0.786 & 0.795 & 0.805 & 0.862 & 0.918 & 0.814 & 0.897 & 0.825 & 0.805 & 0.761 & 0.870 \\
\hline $\mathrm{Na}$ & 0.034 & 0.026 & 0.034 & 0.032 & 0.036 & 0.038 & 0.032 & 0.046 & 0.032 & 0.038 & 0.034 & 0.036 \\
\hline Wo & 41.4 & 40.9 & 45.5 & 42.3 & 44.9 & 46.8 & 42.9 & 44.6 & 43.8 & 41.8 & 38.5 & 45.5 \\
\hline En & 39.5 & 45.2 & 31.5 & 36.3 & 39.8 & 30.3 & 36.5 & 33.6 & 36.6 & 37.1 & 36.4 & 35 \\
\hline Fs & 19.1 & 13.9 & 23 & 21.4 & 15.3 & 22.9 & 20.6 & 21.8 & 19.6 & 21.1 & 25.1 & 19.5 \\
\hline
\end{tabular}


TABLE 4 - Continued

\begin{tabular}{|c|c|c|c|c|c|c|c|c|c|c|c|c|c|c|c|}
\hline \multicolumn{3}{|c|}{$15-2,79-81 \mathrm{~cm}$} & \multicolumn{3}{|c|}{$15-4,114-116 \mathrm{~cm}$} & \multicolumn{3}{|c|}{$16-1,28-30 \mathrm{~cm}$} & \multicolumn{2}{|c|}{$18-1,55-57 \mathrm{~cm}$} & \multicolumn{3}{|c|}{$22-2,61-73 \mathrm{~cm}$} & \multicolumn{2}{|c|}{$22-2,110-120 \mathrm{~cm}$} \\
\hline 48.84 & 46.50 & 47.48 & 47.43 & 47.48 & 46.98 & 47.92 & 47.64 & 48.53 & 46.12 & 48.28 & 47.31 & 45.63 & 46.45 & 46.89 & 47.69 \\
\hline 2.92 & 6.09 & 3.79 & 5.63 & 3.50 & 3.70 & 4.18 & 5.59 & 3.25 & 5.95 & 3.25 & 5.55 & 6.79 & 7.01 & 6.89 & 3.10 \\
\hline 14.48 & 10.08 & 11.85 & 9.68 & 14.09 & 16.99 & 9.00 & 10.73 & 13.36 & 10.47 & 13.65 & 11.48 & 9.02 & 7.83 & 8.57 & 14.87 \\
\hline 0.47 & 0.26 & 0.36 & 0.30 & 0.42 & 0.54 & 0.31 & 0.58 & 0.38 & 0.27 & 0.46 & 0.32 & 0.24 & 0.22 & 0.22 & 0.35 \\
\hline 13.77 & 12.95 & 13.74 & 12.82 & 12.65 & 12.14 & 12.71 & 13.78 & 14.30 & 12.80 & 14.48 & 12.40 & 12.52 & 12.25 & 13.40 & 14.07 \\
\hline 17.82 & 21.29 & 19.57 & 20.94 & 18.50 & 16.46 & 21.88 & 19.62 & 18.38 & 21.10 & 18.08 & 20.50 & 22.87 & 23.28 & 21.33 & 18.03 \\
\hline 0.43 & 0.48 & 0.45 & 0.53 & 0.45 & 0.46 & 0.66 & 0.50 & 0.46 & 0.30 & 0.33 & 0.46 & 0.48 & 0.33 & 0.37 & 0.33 \\
\hline 1.66 & 2.48 & 1.95 & 2.17 & 1.92 & 2.19 & 2.37 & 2.25 & 1.44 & 2.34 & 1.71 & 2.08 & 1.58 & 2.20 & 2.07 & 1.21 \\
\hline 100.39 & 100.12 & 99.19 & 99.51 & 99.02 & 99.46 & 100.03 & 100.69 & 100.10 & 99.35 & 100.23 & 100.10 & 99.12 & 99.41 & 99.74 & 99.65 \\
\hline 1.856 & 1.758 & 1.818 & 1.796 & 1.835 & 1.823 & 1.804 & 1.786 & 1.844 & 1.760 & 1.834 & 1.793 & 1.744 & 1.751 & 1.762 & 1.834 \\
\hline 0.131 & 0.242 & 0.171 & 0.204 & 0.159 & 0.169 & 0.196 & 0.214 & 0.146 & 0.240 & 0.146 & 0.207 & 0.256 & 0.249 & 0.238 & 0.140 \\
\hline- & 0.029 & - & 0.047 & - & - & 0.034 & 0.033 & - & 0.027 & - & 0.041 & 0.050 & 0.064 & 0.067 & - \\
\hline 0.048 & 0.070 & 0.056 & 0.062 & 0.056 & 0.064 & 0.067 & 0.063 & 0.041 & 0.067 & 0.049 & 0.059 & 0.045 & 0.063 & 0.058 & 0.035 \\
\hline 0.460 & 0.319 & 0.379 & 0.307 & 0.455 & 0.551 & 0.283 & 0.336 & 0.424 & 0.334 & 0.434 & 0.364 & 0.288 & 0.248 & 0.269 & 0.478 \\
\hline 0.015 & 0.008 & 0.012 & 0.010 & 0.014 & 0.018 & 0.010 & 0.018 & 0.012 & 0.009 & 0.015 & 0.010 & 0.008 & 0.007 & 0.007 & 0.011 \\
\hline 0.780 & 0.730 & 0.784 & 0.723 & 0.728 & 0.702 & 0.713 & 0.770 & 0.810 & 0.728 & 0.820 & 0.700 & 0.713 & 0.691 & 0.751 & 0.807 \\
\hline 0.725 & 0.862 & 0.803 & 0.849 & 0.766 & 0.684 & 0.883 & 0.788 & 0.748 & 0.863 & 0.736 & 0.832 & 0.936 & 0.944 & 0.859 & 0.743 \\
\hline 0.032 & 0.035 & 0.034 & 0.039 & 0.045 & 0.035 & 0.048 & 0.036 & 0.034 & 0.022 & 0.025 & 0.034 & 0.035 & 0.025 & 0.027 & 0.025 \\
\hline 36.9 & 45.1 & 40.8 & 45.2 & 39.3 & 35.3 & 47 & 41.6 & 37.7 & 44.8 & 37 & 43.9 & 48.3 & 50.1 & 45.7 & 36.6 \\
\hline 39.7 & 38.2 & 39.9 & 38.5 & 37.4 & 36.2 & 37.9 & 40.7 & 40.9 & 37.8 & 41.2 & 36.9 & 36.8 & 36.7 & 40 & 39.8 \\
\hline 23.4 & 16.7 & 19.3 & 16.3 & 23.3 & 28.4 & 15.1 & 17.7 & 21.4 & 17.4 & 21.8 & 19.1 & 14.9 & 13.2 & 14.3 & 23.6 \\
\hline
\end{tabular}




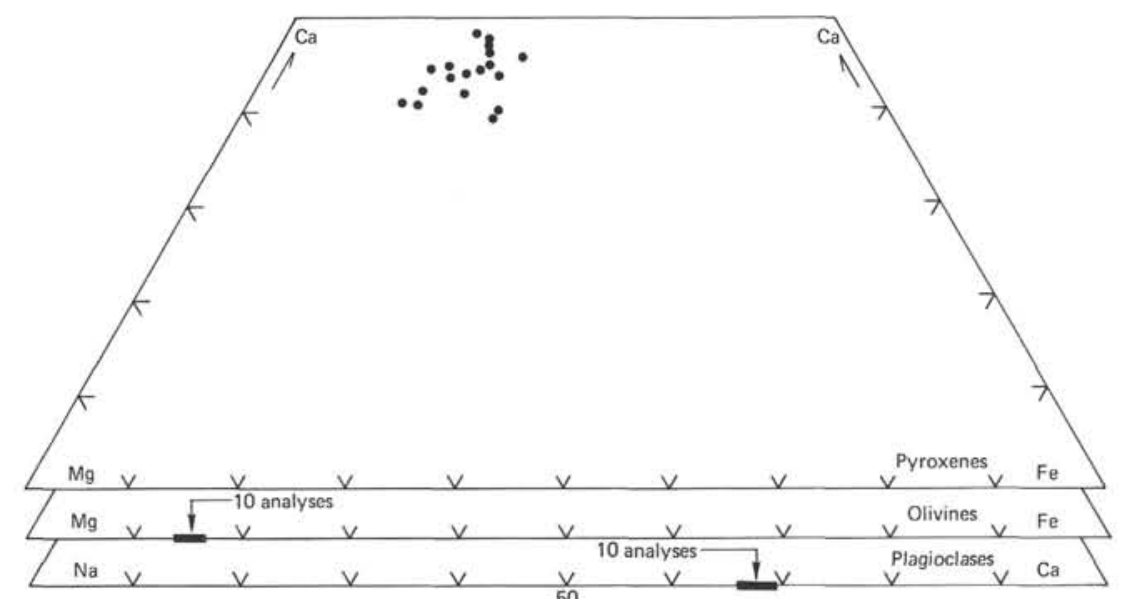

$5 \cdot 2,134 \cdot 135 \mathrm{~cm}, \# 9$

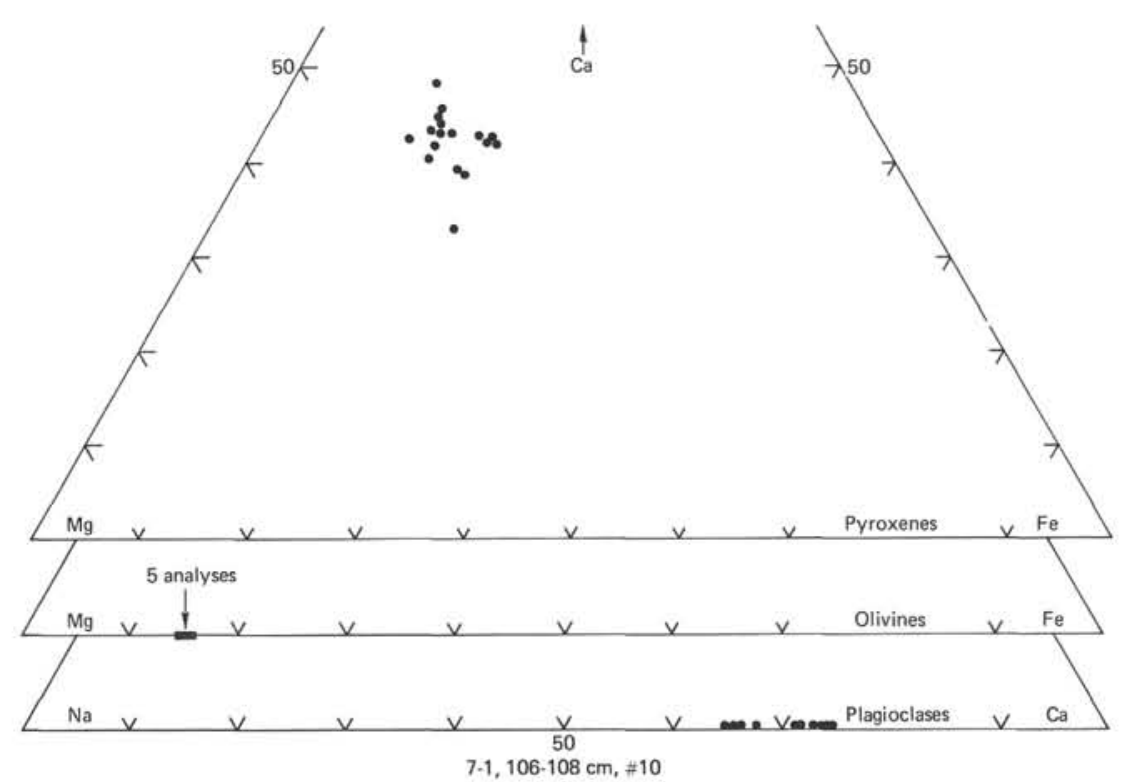

$7-1,106-108 \mathrm{~cm}, \# 10$

Figure 4. $\mathrm{Ca}-\mathrm{Mg}-\mathrm{Fe}$ pyroxene compositions, $\mathrm{Mg}-\mathrm{Fe}$ olivine compositions, and $\mathrm{K}-\mathrm{Ca}-\mathrm{Na}$ plagioclase compositions of the analyzed samples.
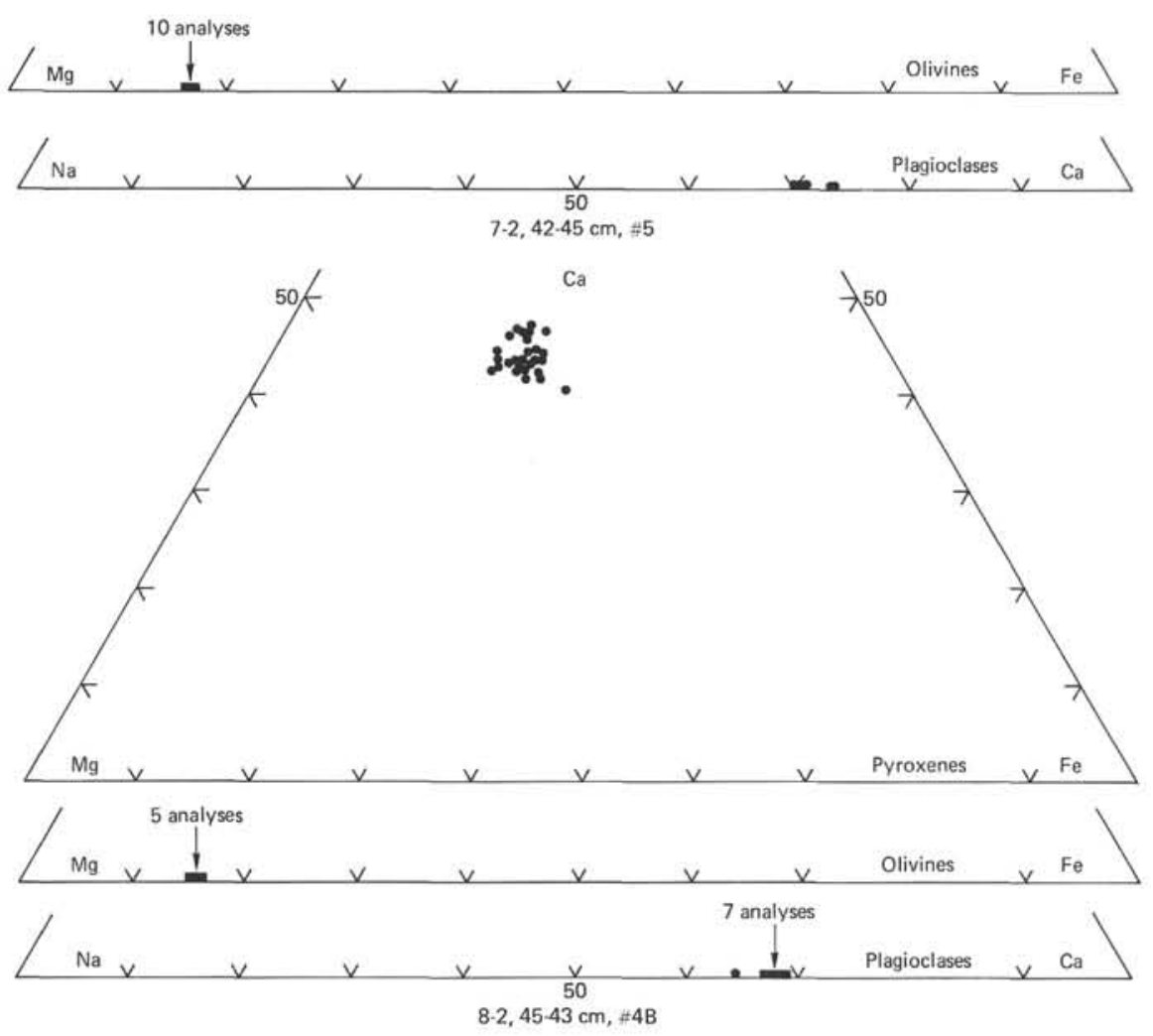

Figure 4. (Continued). 

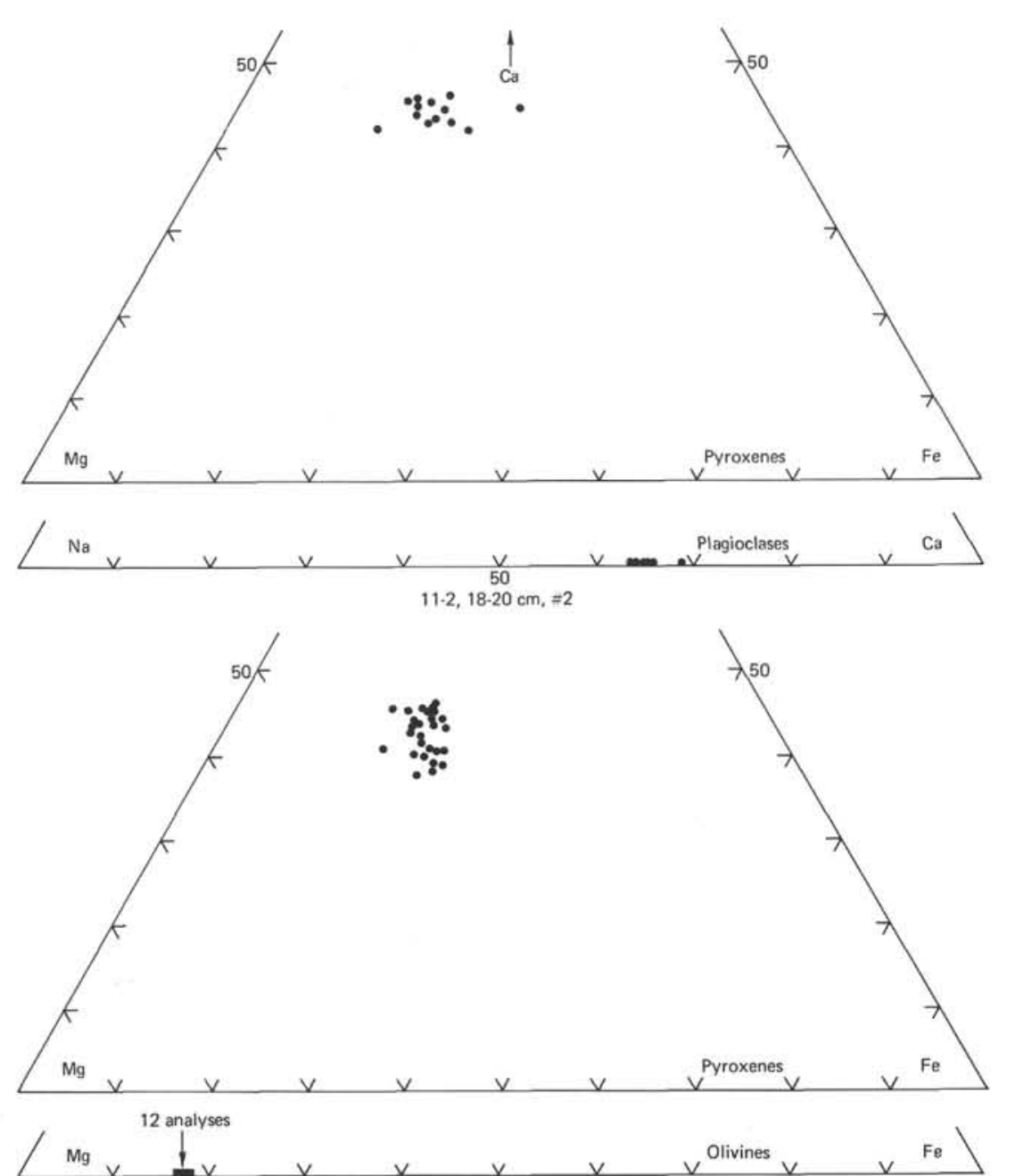

$\int \mathrm{Ti} V$

Figure 4. (Continued).

$14-2,113 \cdot 115 \mathrm{~cm}, \# 11$

$V^{\text {Titanomagnetites }} V^{\mathrm{Fe}}$
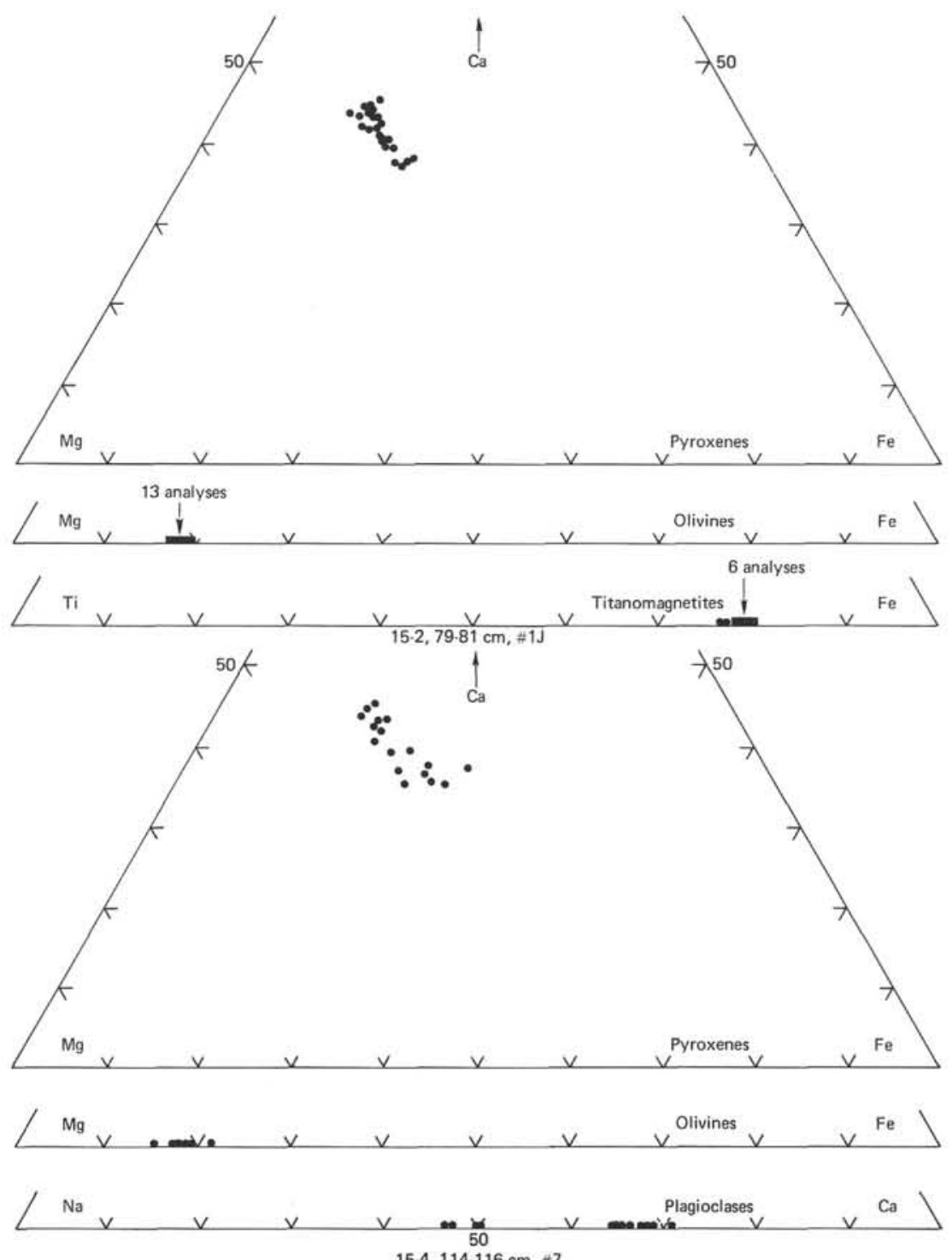

Figure 4. (Continued). 

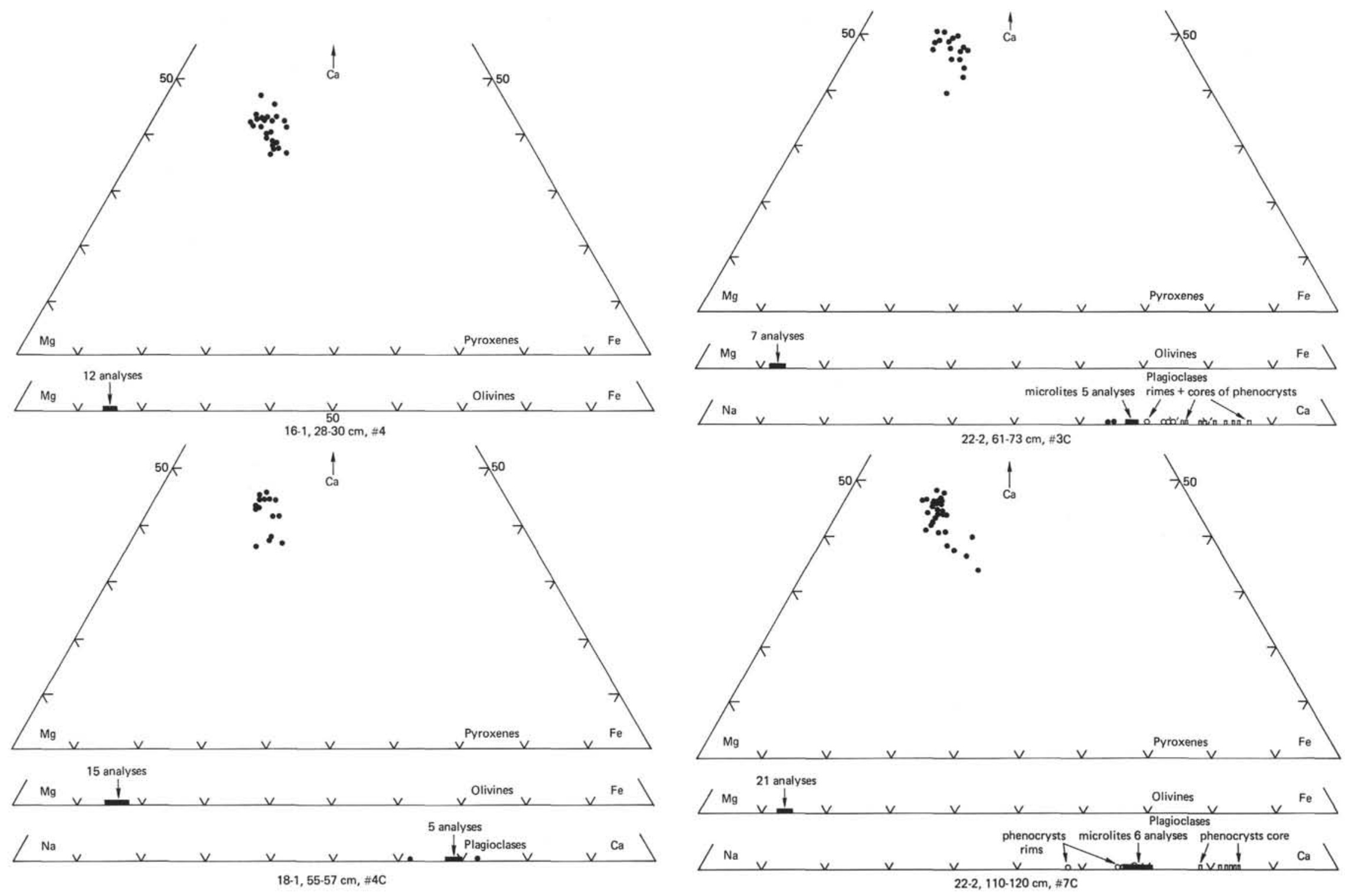

Figure 4. (Continued).

Figure 4. (Continued). 
TABLE 5

Representative Plagioclase Analyzed by Microprobe

\begin{tabular}{|c|c|c|c|c|c|c|c|c|}
\hline Sample & $5-2,134-136 \mathrm{~cm}$ & $7-1,106-108 \mathrm{~cm}$ & $7-1,106-108 \mathrm{~cm}$ & $7-2,42-45 \mathrm{~cm}$ & $8-2,43-45 \mathrm{~cm}$ & $11-2,18-20 \mathrm{~cm}$ & \multicolumn{2}{|c|}{$15-4,114-116 \mathrm{~cm}$} \\
\hline $\mathrm{SiO}_{2}$ & 52.26 & 52.71 & 53.00 & 51.88 & 52.03 & 52.51 & 52.94 & 56.50 \\
\hline $\mathrm{Al}_{2} \mathrm{O}_{3}$ & 30.42 & 30.07 & 30.43 & 30.75 & 30.28 & 29.02 & 29.99 & 27.31 \\
\hline $\mathrm{CaO}$ & 14.42 & 14.80 & 13.47 & 14.26 & 14.15 & 13.29 & 13.77 & 10.00 \\
\hline $\mathrm{Na}_{2} \mathrm{O}$ & 3.57 & 3.05 & 3.90 & 3.37 & 3.63 & 4.12 & 3.97 & 5.59 \\
\hline Total & 100.67 & 100.63 & 100.80 & 100.26 & 100.09 & 98.94 & 100.68 & 99.39 \\
\hline $\mathrm{Si}$ & 9.437 & 9.508 & 9.527 & 9.398 & 9.445 & 9.626 & 9.543 & 10.191 \\
\hline $\mathrm{Al}$ & 6.475 & 6.394 & 6.448 & 6.564 & 6.840 & 6.271 & 6.373 & 5.806 \\
\hline $\mathrm{Ca}$ & 2.790 & 2.861 & 2.595 & 2.768 & 2.753 & 2.611 & 2.660 & 1.932 \\
\hline $\mathrm{Na}$ & 1.249 & 1.065 & 1.360 & 1.182 & 1.277 & 1.463 & 1.388 & 1.956 \\
\hline Z & 15.92 & 15.90 & 15.98 & 15.97 & 15.93 & 15.90 & 15.92 & 16 \\
\hline $\mathrm{X}$ & 4.04 & 3.93 & 3.96 & 3.95 & 4.03 & 4.07 & 4.05 & 3.89 \\
\hline $\mathrm{Ab}$ & 30.9 & 27.1 & 34.4 & 29.9 & 31.7 & 35.9 & 34.3 & 50.3 \\
\hline An & 69.1 & 72.9 & 65.6 & 70.1 & 68.3 & 64.1 & 65.7 & 49.7 \\
\hline
\end{tabular}

TABLE 5 - Continued

\begin{tabular}{lcrrrrrr}
\hline Sample & $18-1,55-57 \mathrm{~cm}$ & \multicolumn{3}{c}{$22-2,61-73 \mathrm{~cm}$} & \multicolumn{3}{c}{$22-2,110-120 \mathrm{~cm}$} \\
\hline $\mathrm{SiO}_{2}$ & 51.84 & 46.34 & 48.70 & 52.19 & 50.76 & 47.57 & 52.09 \\
$\mathrm{Al}_{2} \mathrm{O}_{3}$ & 30.87 & 33.43 & 31.59 & 30.45 & 30.39 & 33.93 & 29.84 \\
$\mathrm{CaO}$ & 14.21 & 17.26 & 15.22 & 14.06 & 13.98 & 17.36 & 14.36 \\
$\mathrm{Na} 2 \mathrm{O}$ & 3.55 & 1.79 & 2.96 & 3.68 & 3.58 & 2.00 & 3.38 \\
$\mathrm{Total}$ & 100.47 & 98.82 & 98.47 & 100.37 & 98.71 & 100.86 & 99.67 \\
$\mathrm{Si}$ & 9.376 & 8.621 & 9.038 & 9.444 & 9.352 & 8.666 & 9.492 \\
$\mathrm{Al}$ & 6.581 & 7.330 & 6.910 & 6.494 & 6.598 & 7.285 & 6.410 \\
$\mathrm{Ca}$ & 2.754 & 3.440 & 3.027 & 2.727 & 2.759 & 3.388 & 2.804 \\
$\mathrm{Na}$ & 1.245 & 0.646 & 6.910 & 1.290 & 1.280 & 0.706 & 1.196 \\
$\mathrm{Z}$ & 15.96 & 15.95 & 15.95 & 15.94 & 15.95 & 15.95 & 15.90 \\
$\mathrm{X}$ & 4.00 & 4.09 & 4.09 & 4.02 & 4.04 & 4.09 & 4.00 \\
$\mathrm{Ab}$ & 31.1 & 15.8 & 26 & 32.1 & 31.7 & 17.2 & 29.9 \\
$\mathrm{An}$ & 68.9 & 84.2 & 74 & 67.9 & 68.3 & 82.9 & 70.1 \\
\hline
\end{tabular}


C. MEVEL, D. OHNENSTETTER, N.

TABLE 6

Representative Olivines Analyzed by Microprobe

\begin{tabular}{|c|c|c|c|c|c|c|c|c|}
\hline Sample & $5-2,134-136 \mathrm{~cm}$ & $7-1,106-108 \mathrm{~cm}$ & $7-2,42.45 \mathrm{~cm}$ & $8-2,43-45 \mathrm{~cm}$ & $14-2,113-115 \mathrm{~cm}$ & \multicolumn{2}{|c|}{$15-2,79-81 \mathrm{~cm}$} & $15-4,114-116 \mathrm{~cm}$ \\
\hline $\mathrm{SiO}_{2}$ & 39.12 & 39.50 & 39.70 & 38.96 & 39.54 & 39.36 & 39.40 & 39.55 \\
\hline $\mathrm{FeO}^{+}$ & 14.08 & 14.38 & 15.44 & 15.13 & 16.21 & 15.84 & 18.64 & 17.07 \\
\hline $\mathrm{MgO}$ & 45.17 & 46.51 & 45.32 & 45.96 & 44.56 & 45.07 & 42.84 & 44.28 \\
\hline Total & 98.37 & 100.39 & 100.45 & 100.05 & 100.30 & 100.27 & 100.88 & 100.90 \\
\hline $\mathrm{Si}$ & 0.995 & 0.985 & 0.993 & 0.961 & 0.994 & 0.989 & 0.996 & 0.993 \\
\hline $\mathrm{Fe}$ & 0.299 & 0.300 & 0.323 & 0.318 & 0.341 & 0.333 & 0.394 & 0.358 \\
\hline $\mathrm{Mg}$ & 1.712 & 1.729 & 1.690 & 1.722 & 1.671 & 1.688 & 1.614 & 1.656 \\
\hline$\Sigma$ & 3.006 & 3.014 & 3.006 & 3.026 & 3.006 & 3.010 & 3.004 & 3.007 \\
\hline $\mathrm{Fa}$ & 14.9 & 14.8 & 16 & 15.8 & 16.9 & 16.5 & 19.6 & 17.8 \\
\hline Fo & 85.1 & 85.2 & 84 & 84.2 & 83.1 & 83.5 & 80.4 & 82.2 \\
\hline
\end{tabular}

TABLE 6 - Continued

\begin{tabular}{ccccccc}
\hline $16-1,28-30 \mathrm{~cm}$ & \multicolumn{2}{c}{$18-1,55-57 \mathrm{~cm}$} & $22-2,61-73 \mathrm{~cm}$ & \multicolumn{3}{c}{$22-2,110-120 \mathrm{~cm}$} \\
\hline & & & & Core & \multicolumn{1}{c}{ Rim } \\
40.00 & 40.70 & 40.10 & 38.69 & 38.62 & 39.41 & 38.11 \\
13.55 & 14.96 & 16.91 & 11.78 & 12.87 & 13.62 & 13.73 \\
46.89 & 44.42 & 43.27 & 48.69 & 47.14 & 47.43 & 48.93 \\
100.44 & 100.08 & 100.28 & 99.16 & 98.64 & 100.46 & 100.77 \\
& & & & & & \\
0.992 & 1.017 & 1.010 & 0.968 & 0.976 & 0.975 & 0.949 \\
0.281 & 0.312 & 0.356 & 0.247 & 0.272 & 0.278 & 0.286 \\
1.734 & 1.654 & 1.624 & 1.816 & 1.776 & 1.772 & 1.816 \\
3.007 & 2.983 & 2.990 & 3.031 & 3.024 & 3.025 & 3.051 \\
13.9 & 15.9 & 18 & 12 & 13.3 & 13.6 & 13.6 \\
86.1 & 84.1 & 82 & 88 & 86.7 & 86.4 & 86.4 \\
\hline
\end{tabular}

TABLE 7

Representative Partial Titanomagnetite Analyzed by Microprobe

\begin{tabular}{lcccc}
\hline \multicolumn{1}{c}{ Sample } & \multicolumn{2}{c}{$14-2,113-115 \mathrm{~cm}$} & \multicolumn{2}{c}{$15-2,79-81 \mathrm{~cm}$} \\
\hline $\mathrm{FeO}^{+}$ & 64.98 & 63.52 & 69.50 & 70.32 \\
$\mathrm{TiO}_{2}$ & 20.54 & 24.02 & 21.04 & 20.39 \\
$\mathrm{Total}$ & 85.53 & 87.54 & 90.10 & 90.71 \\
& & & & \\
$\mathrm{Fe}$ & 6.375 & 5.952 & 6.475 & 6.572 \\
$\mathrm{Ti}$ & 1.812 & 2.024 & 1.763 & 1.714 \\
$\Sigma$ & 8.87 & 7.976 & 8.238 & 8.286 \\
(on the & & & & \\
basis of & & & & \\
10 oxygens & & & & \\
\hline
\end{tabular}

